\title{
Real-time imaging of bacteria/osteoblast dynamic co-culture on bone implant material in an in vitro post-operative contamination model
}

Victor Prévost ${ }^{1,2,4}$, Karine Anselme ${ }^{1,2}$, Olivier Gallet ${ }^{4}$, Mathilde Hindié ${ }^{4}$, Tatiana Petithory ${ }^{1,2}$, Jules Valentin ${ }^{1,2}$, Mathieu Veuillet ${ }^{1,2}$, Lydie Ploux*1,2,3

${ }^{1}$ Université de Haute-Alsace, CNRS, IS2M UMR 7361, F-68100 Mulhouse, France

2 Université de Strasbourg, France

3 Université de Strasbourg, INSERM, BIOMAT U1121, F-67000 Strasbourg, France

${ }^{4}$ Université de Cergy-Pontoise, ERRMECe, F-95000 Neuville-sur-Oise, France

*Corresponding author: ploux@unistra.fr

\begin{abstract}
Biomedical implants are an important part of evolving modern medicine but have a potential drawback in form of post-operative pathogenic infection. Accordingly, the "race for surface" combat between invasive bacteria and host cells determines the fate of implants. Hence, proper in vitro systems are required to assess effective strategies to avoid infection. In this study we developed a real time observation model, mimicking post-operative contamination, designed to follow E. coli proliferation on titanium surface occupied by human osteoblastic progenitor cells (STRO). This model allowed us to monitor E. coli invasion of human cells and titanium surface coated and uncoated with fibronectin. We showed that the surface colonization of bacteria is significantly enhanced on fibronectin coated surfaces irrespective of if areas were uncovered or covered with human cells. We further revealed that bacterial colonization of the titanium surfaces is enhanced in co-culture with STRO cells. Finally, this co-culture system provides a comprehensive system to describe in vitro and in situ bacterial and human cells and their localization but also to target biological mechanisms involved in adhesion as well as in interactions with surfaces, thanks to fluorescent labelling. This system is thus an efficient method for studies related to design and function of new biomaterials.
\end{abstract}




\section{KEYWORDS}

Real-time imaging, bacteria/eukaryotic cells co-culture, biomaterials, confocal fluorescence microscopy, fibronectin

\section{INTRODUCTION}

A major challenge in bone implant integration is the prevention of biomaterials associated infection (BAI). The consequences of BAl for patients are severe as their hospitalization time is increased and may sometimes lead to complementary surgery. ${ }^{1-2}$ BAl are commonly studied in vitro with either eukaryotic or prokaryotic cells. ${ }^{3-10}$ The "race for the surface" ${ }^{11}$ between bacteria and cells during $\mathrm{BAl}$, has been more recently reproduced in vitro using a co-culture model with host cells and bacteria. The simplest in vitro BAI models on various biomaterials are based on static co-cultures of human eukaryotic cells (gingival fibroblasts or osteoblasts) with different strains of Streptococci, ${ }^{12-16}$ Pseudomonas $^{17-18}$ or Staphylococci ${ }^{19-21}$ in multi-well plates. Even though these models provide a wealth of knowledge their preparatory procedures along with chemical fixation to quantify the amount and viability of cells or bacteria are done long after the co-culture is initiated. Due to this the initial events of interaction between material-cell/bacteria and cell-bacteria remains largely unexplored.

Thus, there is a need to develop the existing methods in order to explore the preliminary interactions of cell and bacteria on implants. In situ optical microscopies can allow continuous observation of real-time interactions in co-cultures. When equipped with culture set-ups to provide continuous nutrient medium exchange, these systems, furthermore, provide adequate conditions for live cells and bacteria. In 2000, Heydorn et al. used such a hydrodynamic system to evaluate in vitro reproducibility of biofilms. ${ }^{22}$ Later on, microfluidic systems were applied to cellular or bacterial culture separately..$^{23-24}$ However, while they enabled real-time imaging under flow, these devices were inadequate for investigating large pieces of biomaterial. Considering this, in 2006 Busscher and Van der Mei proposed a new type of flow chamber, which allowed working with a bigger volume of culture medium and larger culture surfaces. ${ }^{25}$ In 2009, the same group proposed for the first time a prokaryote and eukaryote co-culture model based on previously developed flow chamber. ${ }^{26}$ Later, this co-culture model was used to evaluate the simultaneous response of Staphylococci and 
osteoblasts on different materials. ${ }^{27-31}$ In 2011, they improved their co-culture model by associating three different bacterial strains, macrophages and osteoblasts to study tissue integration in BAI context. ${ }^{32}$ However, chemical fixation of cells was still needed in this model before their observation.

Lee et al. have provided significant advances to the field by an attempt to simulate 3D tissue with osteoblastic cells in an in vitro co-culture system, designed to simulate BAI with $S$. epidermidis in actual organs. ${ }^{24}$ Nevertheless, most of these approaches focused on specific biological behaviors resulting from the bacteria/cell co-culture, without any consideration for biological interactions with the underlying material. Aiming at mimicking clinically relevant cells/bacteria/material complex environments, in 2014 Yue et al. focused on the interaction of bacteria and cells with active titanium surfaces. ${ }^{33}$ However, bacteria-cell interaction was not evaluated and the system did not allow dynamic fluid circulation or real-time imaging of the co-culture. The most comprehensive co-culture model developed until now was reported by Lee et al. while studying interactions between mouse osteoblasts (MC3T3-E1) and S. epidermidis on a titanium surface by real-time imaging and recording live cells and bacteria under an upright fluorescent microscope. ${ }^{34}$ However, images of both cells and bacteria could not be obtained at the same time.

Thus ultimately, there is still a lack of a co-culture system that includes all the methodologies and experimental approaches needed to provide a thorough and dynamic description of interactions between mammalian cells, bacteria and materials. Such a dynamic microfluidic flow system would allow renewing culture medium of fluorescently stained cells and bacteria and real-time florescence imaging at high resolution of material-cell/bacteria and cellbacteria interactions. With this aim we developed a versatile and reliable system based on a flow chamber designed for investigation of any biomaterial. ${ }^{35-36}$ Previous studies postulated bacterial adhesion prior to cell arrival on the implant, in order to simulate an infection occurring during the operation and before tissue integration. ${ }^{26}$ Herein, we explore another aspect of implant contamination by focusing on the infection by bacteria of cells previously adhered to the biomaterial. This situation can occur during early stage of tissue integration or when integration is already achieved i.e. a post-operative contamination model. ${ }^{28}$ 
With this objective, we attempted to develop a dynamic system to control cell viability and mimic arrival of bacteria via bloodstream by renewing culture medium through use of a peristaltic pump. Moreover, our aim was to deal with orthopedic materials such as ceramic or titanium with variable surface chemistry and topography. With the help of an upright confocal laser microscope equipped with a $63 \mathrm{X}$ magnification objective of high optical aperture, well-adapted for imaging bacteria, we imaged in situ bacteria/cell growth on such opaque materials. Furthermore, we optimized the set-up previously designed by our lab. ${ }^{36}$ Notably the distance between the material sample and the microscope objective was adapted to the short focal-length of the objective and for the reduction of the culture medium height crossed by light. To be able to follow the behavior of both bacteria and cells, their staining became a key factor. Thus, for bacteria, we took advantage of GFP-expressing bacteria technology. ${ }^{37}$ For cells, labeling required adjustments to compromise on sufficient fluorescence emission versus oxidative toxicity resulting from photo-bleaching. ${ }^{38-40}$ Thus, the real-time and high magnification imaging of the initial contamination of pre-adhered osteoblastic progenitor cells by $E$. coli on clinically non-transparent relevant titanium surfaces became possible.

\section{MATERIALS AND METHODS}

\subsection{Flow chamber design and circuit construction}

Flow chamber and procedures were designed on the basis of set-ups and procedures developed for investigation of bacteria/material interface and described previously. ${ }^{35-36}$ The flow chamber was fabricated out of polycarbonate Makrolon ${ }^{\mathrm{TM}}$ (NEOTEC Plastique SAS, France). It exhibits a co-culture chamber with a $20 \times 40 \mathrm{~mm}$ flat bottom and a height of $1.8 \mathrm{~mm}$. These dimensions allow the incorporation of large surface material, e.g. $16 \mathrm{~mm}$ diameter titanium disks in a centered circular cavity. The total volume of the chamber $(1.44 \mathrm{ml})$ contains enough culture medium to ensure cell viability during non-dynamic phases (cell adhesion to surface, bacteria adhesion to surface, cell fluorescent staining). The chamber was sealed by a $0.17 \mathrm{~mm}$ thick glass cover slip (Menzel-Gläser, Fisher Scientific, France) with the help of a thin line of biocompatible glue (Aqua SiliconeTM, Den Braven, Netherlands). The use of this wide glass cover slip gives a large field of view and allows scanning the entire surface of the material 
with minimum adjustments. The input and the output sides of the chamber were connected to the circuit by $0.5 \mathrm{~mm}$ diameter cylindrical holes on which were plugged flexible tubes (TYGON R-3603, Fisher Scientific, France) (Figure 1). A peristaltic pump (ISMATEC ISM945D, Fisher Scientific, France) provided fresh culture medium through the circuit at the constant flow of $0.028 \mathrm{ml} / \mathrm{min}(1.68 \mathrm{ml} / \mathrm{h})$ except during inoculation with bacteria $(0.28 \mathrm{ml} / \mathrm{min})$ to mimic short inoculation phase duration ( $<10 \mathrm{~min}$ ). The medium is stored in a sterile bottle connected to the circuit across a $0.22 \mu \mathrm{m}$ Millipore filter, which prevents undesired chamber contamination. Indeed, this medium does not contain antibiotics, and therefore is vulnerable to bacterial proliferation. A manual valve is used to switch between medium and bacterial solution for starting and stopping the infection step. A tube leads from the valve to the plugged $2 \mathrm{ml}$ syringe that contains the bacterial solution. A passive bubble trap extracts gas bubbles out of the incoming medium. ${ }^{41}$ Then the chamber volume is gently renewed by a laminar flow as evaluated elsewhere. ${ }^{36}$ The observation phase flow is $1.68 \mathrm{ml} / \mathrm{h}$ and the total chamber volume is changed every $51 \mathrm{~min}$. Outcoming medium is driven to the waste bottle. The entire circuit fits under an upright confocal microscope (Carl Zeiss LSM700) within an environmental chamber. During experiments, temperature is maintained at $37^{\circ} \mathrm{C}$ and the atmosphere inside the environmental chamber is a mixture of air and $5 \% \mathrm{CO}_{2}$. The air mixture reaches the culture medium through gas exchange across porous circuit wires.

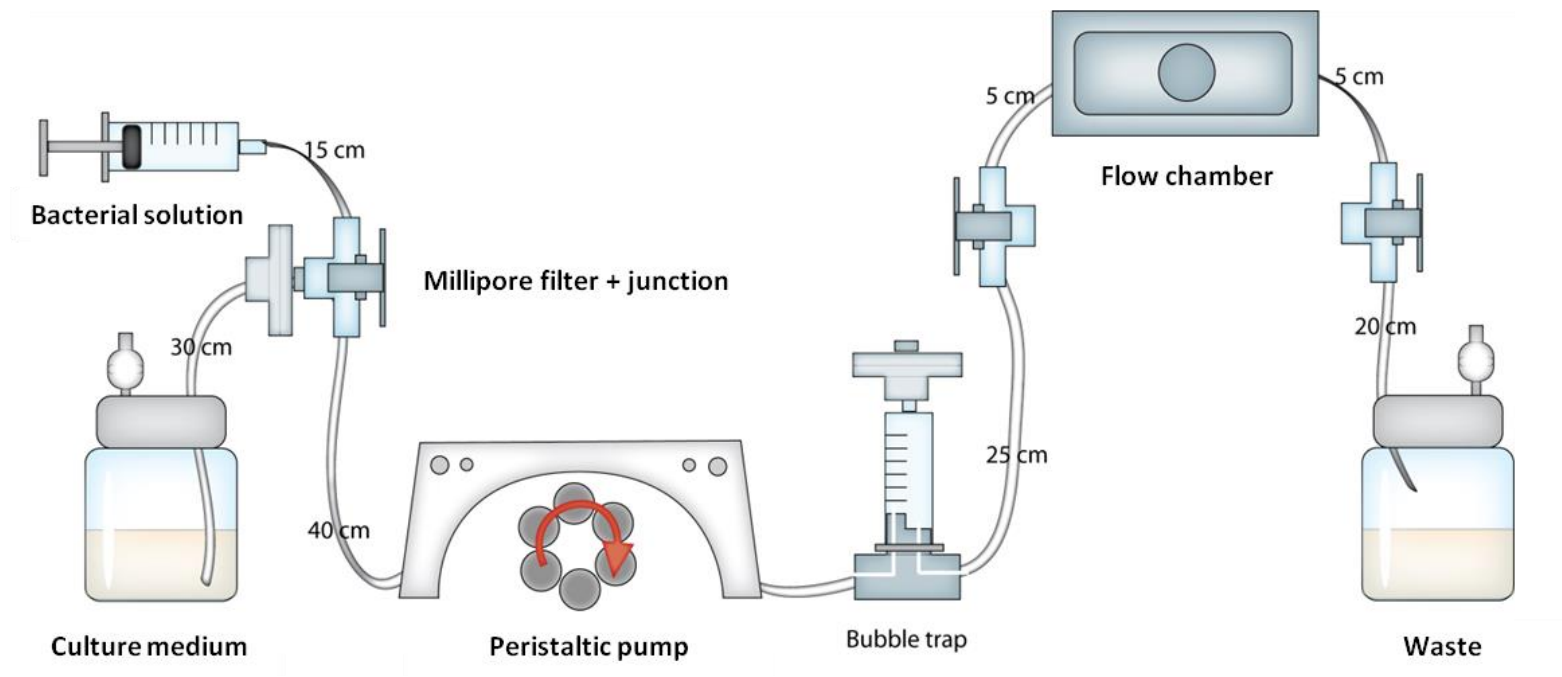

Figure 1 : Scheme of the nutrient and inoculation circuit for co-culture in flow chamber. 


\subsection{Microscopy techniques: Confocal objective and automation}

Observation was performed with an upright confocal microscope (Carl Zeiss LSM700). Upright configuration permits to solve part of the biological versus material concern, as opaque implantable material such as titanium will be observed from the top when cells is growing upon it. A W Plan-Apochromat 63x/1.0 from Zeiss with a $2.1 \mathrm{~mm}$ focal distance was used. This objective is designed for immersion in water and does not possess an optical correction for glass coverslip. However, it was shown to be efficient for bacteria and cell imaging on biomaterials through the liquid (distillated water drop) / transparent solid (glass coverslip) / liquid (culture medium) optical interfaces of the sealed flow chamber (Figure 2). Compared to 50x long distance air objective micrographs, on the same flow chamber, the acquired information is greatly improved, both quantitatively and qualitatively (Figure S1).

The confocal microscope is equipped with a motorized $X-Y$ stage that permits an automated acquisition on various surface locations. Eight positions were fixed the beginning of experiment. Evolution of the surface colonization was then automatically followed on these locations throughout the duration of the experiment (Figure $2 \mathrm{~b}$ ).
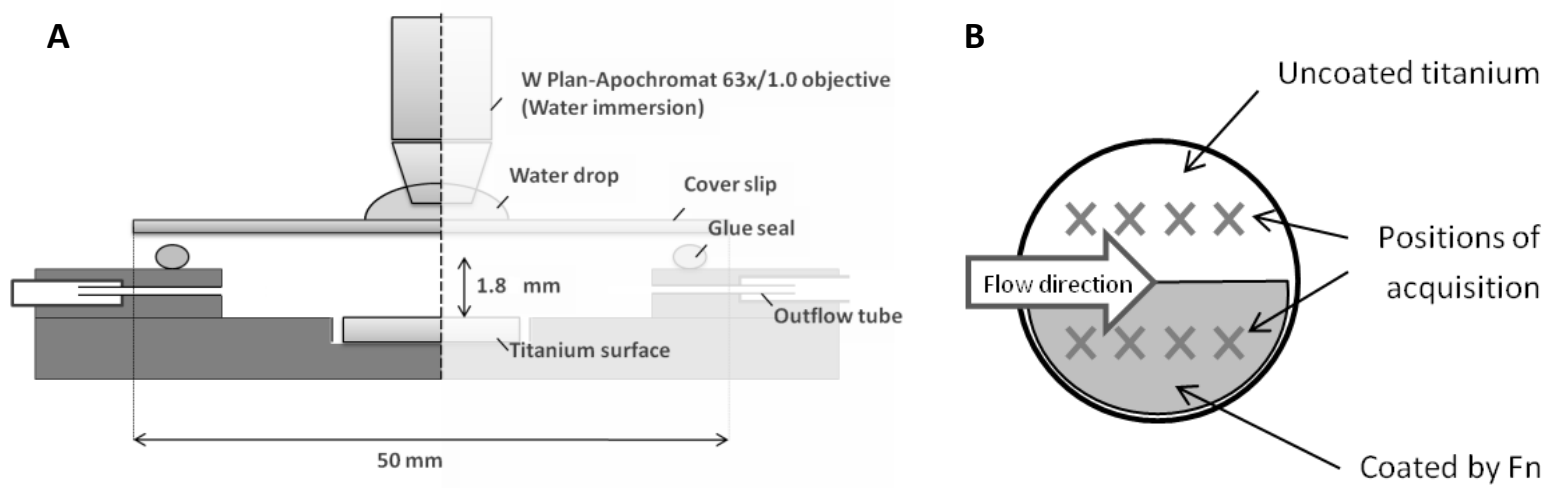

Figure 2 : Setting of the flow chamber under upright confocal microscope $(A)$ and positions of image acquisition on the titanium surface uncoated or coated by human plasma-derived fibronectin (Fn) (B).

\subsection{Biomaterial and fibronectin surface functionalization}

The material used was a mirror polished titanium disk of $16 \mathrm{~mm}$ diameter and $0.5 \mathrm{~mm}$ height provided by Prof. H. Pelletier (INSA, Strasbourg). The disk was cleaned by successive ultrasonic baths in PBS-SDS 1\%, Acetone, Chloroform, Ethanol (15 min each), dried with nitrogen gas 
and then heat-sterilized $\left(180^{\circ} \mathrm{C}, 1 \mathrm{~h}\right)$. The titanium surface was functionalized with $50 \mu \mathrm{g} / \mathrm{ml}$ human plasma-derived fibronectin (Fn) during $30 \mathrm{~min}$ at room temperature, then rinsed three times with sterile PBS and stored in sterile PBS. ${ }^{42}$ To allow the simultaneous study with and without fibronectin culture conditions, only half of the surface was coated with fibronectin by immersing half of the titanium surface in fibronectin solution (Figure 3.D). The coating was visualized by immunostaining with F3648 anti-Fn antibody (Sigma) and the corresponding secondary antibody labelled to TRITC. (Figure 3.A, B, C).
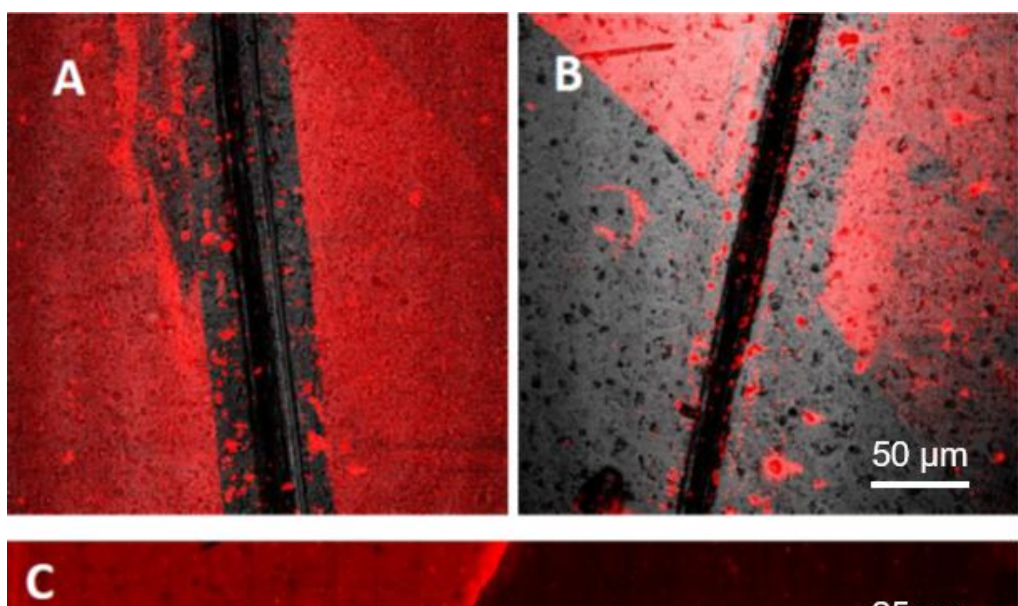

$25 \mu \mathrm{m}$

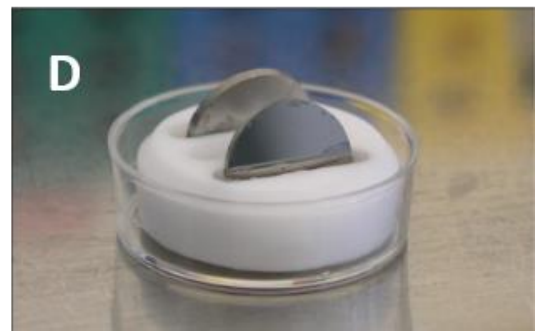

Figure 3: Immunostaining (red) of human plasma fibronectin coated on half titanium surface. (A) A scratch on the surface after staining enables to visualize the fibronectin layer revealed by fluorescent labeling. Boundary between coated and uncoated surface is observed in (B) and (C) surfaces. Size of (A) and (B) micrographs is $256 \mu \mathrm{m} \times 256 \mu \mathrm{m}$. (D) Image showing immersion of half surface of titanium substrate in solution of fibronectin.

\subsection{Cell culture and medium}

The eukaryotic cells F/STRO-1+A (STRO) i.e. immortalized osteoblast progenitors from human fetal bone marrow stroma were a kind gift from Dr Pierre J. Marie (Inserm U1132, University Paris Diderot). Cells used were between $20^{\text {th }}$ and $35^{\text {th }}$ passage to maintain the homogeneity of the observed population. STRO cells were cultured in ISCOVE's modified Dulbecco's Medium (IMDM, Gibco) supplemented with $10 \%$ of Fetal Bovine Serum (FBS) (v/v), $2 \mathrm{mM}$ of L-glutamine and $100 \mathrm{U} / \mathrm{ml}$ penicillin-streptomycin $(100 \mu \mathrm{g} / \mathrm{ml}$ ) solutions (further on referred to as complete medium). They were maintained at $37^{\circ} \mathrm{C}$ in $5 \% \mathrm{CO}_{2}$ humidified atmosphere 
and were passaged at $80-90 \%$ confluence using 5\% (v/v) Trypsin-EDTA. Cell density used was $7.510^{4} \mathrm{cell} / \mathrm{ml}$, and injected in the sealed flow chamber before each experiment and incubated overnight to promote cell adhesion.

\subsection{Bacterial culture and medium}

Prokaryote cells were modified Escherichia coli (K12 SCC1) which express the eGFP fluorescent molecule. They were obtained from Prof. Chun Chau (Division of Genomics \& Genetics, Nanyang Technological University). ${ }^{43}$ Bacteria were thawed from $-80^{\circ} \mathrm{C}$ storage solution, and grown overnight at $30^{\circ} \mathrm{C}$ on Luria Broth (LB) agar medium in Petri dish. One colony was used to inoculate $15 \mathrm{ml} \mathrm{LB}$ solution before overnight incubation at $30^{\circ} \mathrm{C}$. Lag-phase of bacterial growth was obtained by inoculating $30 \mathrm{ml}$ of LB solution with the previously incubated bacterial solution. After 4 hours of growth, the Lag-phase solution was centrifuged (3500 rpm during $20 \mathrm{~min}$ at $4^{\circ} \mathrm{C}$ ) and the medium was replaced by the co-culture medium. Bacterial concentration of this solution was estimated by measurement of absorbance at 600 $\mathrm{nm}$ wavelength. This solution was diluted in co-culture medium to obtain a final $2 \mathrm{ml}$ solution at an optical absorbance of $0.01\left(\sim 510^{6}\right.$ bacteria $\left.\mathrm{mL}^{-1}\right)$, stored in a $5 \mathrm{ml}$ syringe which was plugged into the flow chamber circuit.

\subsection{Co-culture medium}

Co-culture experiments were carried out in a cell culture medium adequate for mammalian cells, in order to describe in a close manner in situ cell behavior in context of implant contamination. Phenol red-free ISCOVE medium was used to minimize interactions with fluorochromes and to optimize microscope laser signal in red wavelengths. Phenol red-free ISCOVE medium was supplemented with $5 \%$ of FBS and $1 \%$ of L- glutamine (referred as coculture medium) and was verified to allow normal growth of bacteria (Figure 4). The coculture medium was maintained at $37^{\circ} \mathrm{C}$ before and during the experiments. 


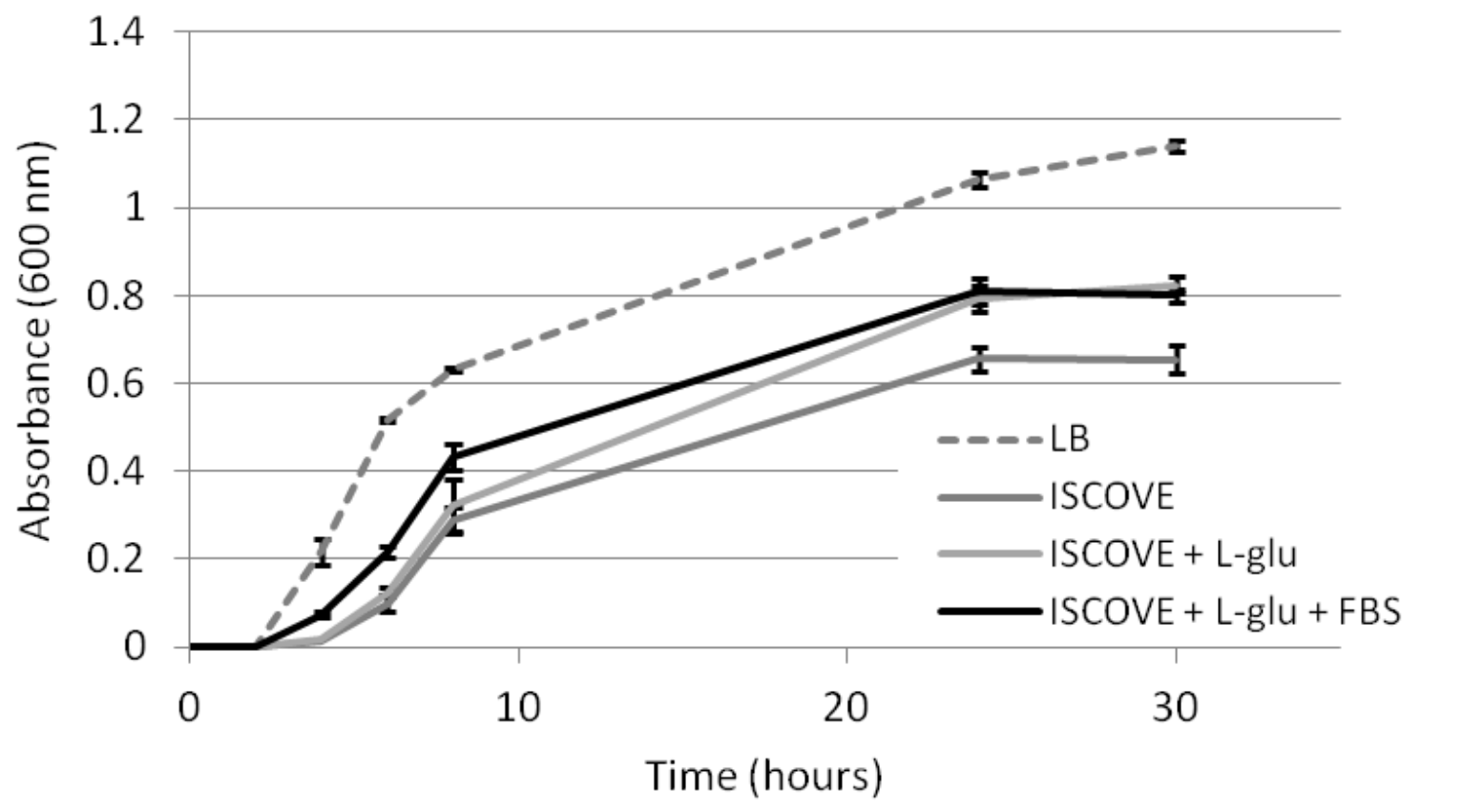

Figure 4: E. coli SCC1 growth in different media with time: Luria Broth (LB), ISCOVE, ISCOVE $+1 \%$ Lglutamine, ISCOVE + 1\% L-glutamine + 5\% FBS.

\subsection{Bacterial inoculation in the co-culture chamber}

Bacterial inoculation phase followed three steps: 1) the syringe content was pumped through the circuit to the co-culture chamber with a flow of $0.28 \mathrm{ml} / \mathrm{min} ; 2$ ) Once the total volume of the bacterial solution had replaced the flow chamber volume, the pump was stopped and the circuit closed before and after the flow chamber to avoid undesired flow movements during the sedimentation of bacteria. The sedimentation phase was maintained for 10 minutes, which is the estimated time needed by bacteria to reach and adhere to the titanium surface; 3) The volume of co-culture chamber was then replaced with fresh medium at a $0.28 \mathrm{ml} / \mathrm{min}$ flow, in order to rinse out planktonic bacteria without displacing the adhered ones. When 2 $\mathrm{ml}$ of fresh medium was pumped through the circuit, the flow was set to $0.028 \mathrm{ml} / \mathrm{min}$ for the rest of the experiment.

\subsection{Labelling of cells}

To assess STRO cell behavior in real-time during bacterial contamination, their membrane was stained prior to the beginning of the experiment. Staining of live STRO cells was performed with Cell Tracker Red dye (CellTracker Red CMTPX Dye, Invitrogen, USA) by injection into the 
flow chamber through the junction that is also used to connect the syringe for injection of the bacterial solution (Figure 1). This was done after overnight adhesion of cells onto the titanium surface. $2 \mathrm{ml}$ of $10 \mu \mathrm{M}$ Cell Tracker Red dye solution (diluted in red phenol free ISCOVE medium) was gently injected in the flow chamber after removing culture medium. Cells were incubated with the stain solution during 30 minutes at $37^{\circ} \mathrm{C}$ with $5 \% \mathrm{CO}_{2}$, and then incubated during 30 minutes with co-culture medium. Afterwards, medium was renewed with fresh coculture medium, and the flow chamber was left for 30 minutes at $37^{\circ} \mathrm{C}$ with $5 \% \mathrm{CO}_{2}$ atmosphere until the start of experiment.

\subsection{Confocal microscope settings}

Acquisition parameters were set on ZEN ${ }^{\circledR}$ software for Zeiss confocal microscope. For each of the 8 positions on the titanium surface, the microscope automated plate was configured to capture 10 images following the $z$ axis, which resulted in $10.49 \mu \mathrm{m}$ thick 3D stacks. The microscope pinhole was maintained below 1 Airy Unit (52 $\mu \mathrm{m}) .555 \mathrm{~nm}$ and $488 \mathrm{~nm}$ lasers were used to excite Cell Tracker Red (with $4.0 \%$ of the maximal laser power), and eGFP fluorochromes (with $4.6 \%$ of the maximal laser power) respectively. The W Plan Apochromat $63 \times$ objective was used at $0.5 \mathrm{X}$ zoom and final images resulted of $4 \times 4$ tile scan merged with $10 \%$ overlap. Gain levels of the photomultipliers were maintained in the range of linearity.

\subsection{Image analysis}

Bacterial counting, cell area calculation and comparison of the surface areas occupied by cells versus bacteria were processed using Image $J^{\circledR}$ software (NIH, version 2.0.0-RC-61/1.51n, USA), with "Analyze Particles" and "Image calculator" functions. ${ }^{44}$ Each acquisition was composed of two tracks i.e. cell and bacterial track corresponding to the red and green channel respectively. Z-projection function was applied to the cell track to reduce the acquired 3D stacks into a 2D image that contains all the information about cell shape and cell area. Zprojection was also applied to bacterial stack to measure bacterial density. 3D observations were done with unreduced stacks (see Results). Measurements were done after setting the upper grayscale threshold in order to get higher signal/noise ratio. Objects were then identified and saved as binary images from which noise was removed. Final data such as cell 
number, shape (circularity, perimeter), area and bacterial size and number were extracted

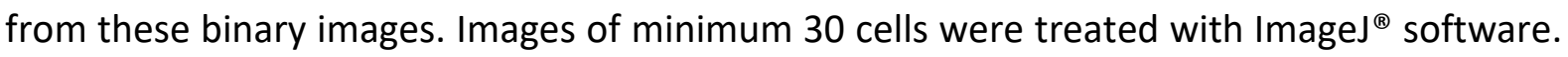
Circularity was calculated by using the formula $4 \pi\left(a r e a /\right.$ perimeter $\left.^{2}\right)$ while Area and Perimeter correspond respectively to the area of the selection and the length of the outside boundary of the selection. The total population of adhered bacteria was measured as the number of bacteria adhered on each micrograph. Besides, two sub-populations were determined: The population of bacteria adhered on the titanium (uncoated or coated with fibronectin) are called as "on substrate"; The population of bacteria adhered on the cells are called as "on cell". The sub-populations are distinguished from each other by superposing the mask of the cells as determined on the Z-projection of the cell track on the Z-projection of the bacterial track. Experiments were repeated at least three times.

\subsection{Statistical analysis}

Results are depicted as the average and standard deviation (error bars) of the experimental values. The statistical significance of differences was assessed by bilateral Student's $t$ tests and ANOVA with significance threshold of 0.05 . The alternative hypothesis $\left(H_{1}: \mu_{1} \neq \mu_{2}\right)$ was assumed to be true when the main hypothesis $\left(H_{0}: \mu_{1}=\mu_{2}\right)$ was rejected..$^{45}$

\section{RESULTS}

\subsection{Live imaging}

With the help of our experimental set up, we were able to visualize both live eukaryotic and prokaryotic cells during the initial time period of infection by bacteria of titanium surfaces already colonized by eukaryotic cells. As shown in Figure 5, the quality of images was high enough to allow further image treatment and analysis for a precise quantification of cell area, cell shape and bacterial number (Figure S3). In addition, 3D visualization provided information about the organization of bacterial consortium and their localization relative to mammalian cells (Figure S4), as illustrated by Figures 6A.1 and 6A.2. This further allowed us to study potential correlation between bacteria and cell localizations. On the uncoated and fibronectin coated titanium substrates, the density of bacteria appeared not to be affected by cell contact. 


\section{$-\mathrm{Fn}$}
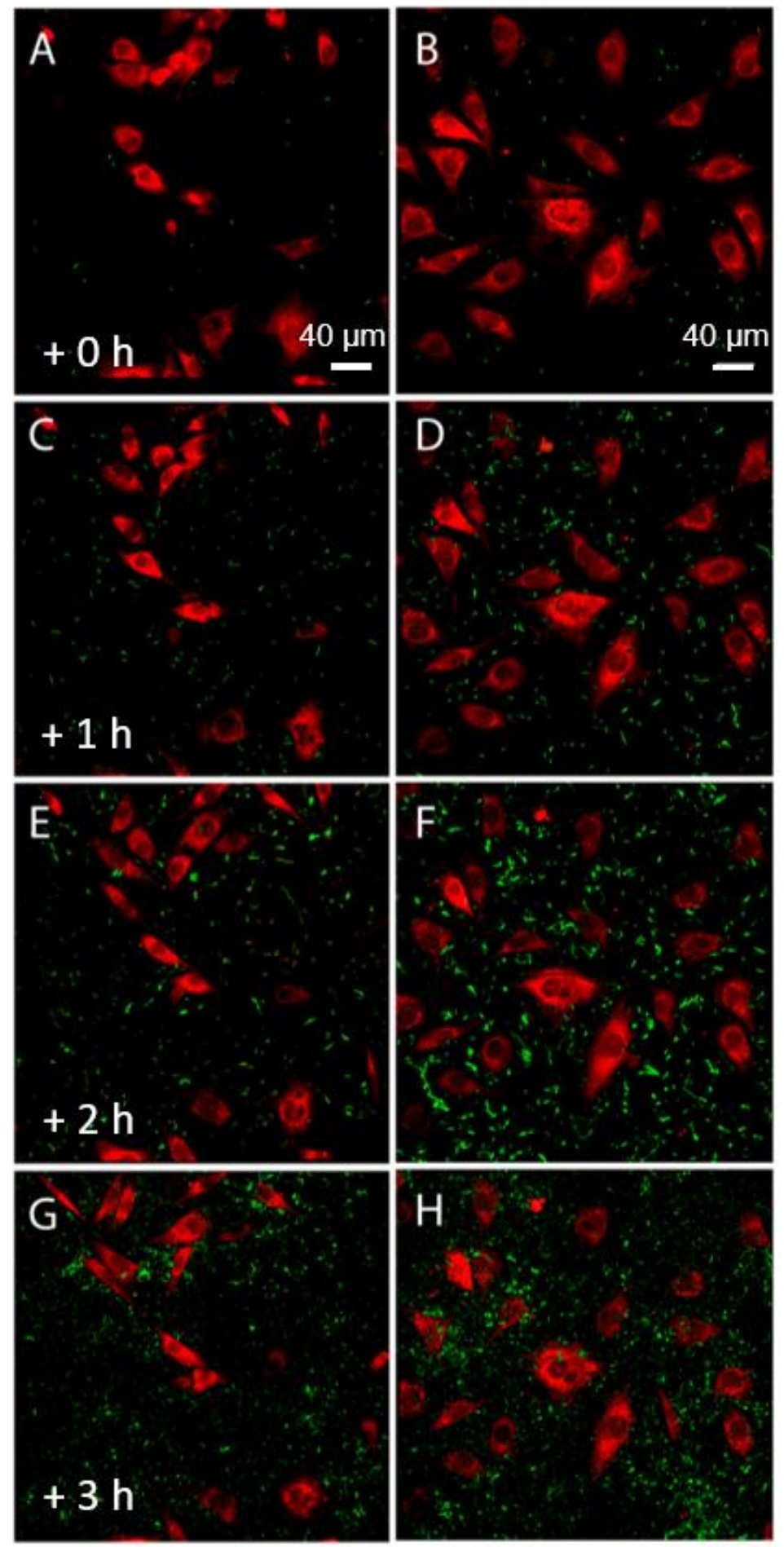

Figure 5: Fluorescent real-time images of STRO cells (in red) in co-culture with bacteria E. coli (in green) adhered on titanium surface without $(-F n)(A, C, E, G)$ and with (+Fn) fibronectin coating $(B, D, F, H)$. Images were obtained at $\Delta t=O(A, B), 1(C, D), 2(E, F)$ and $3(G, H)$ hours after infection and removal with fresh medium of the planktonic bacteria (step 3, see Experimental Section above). 

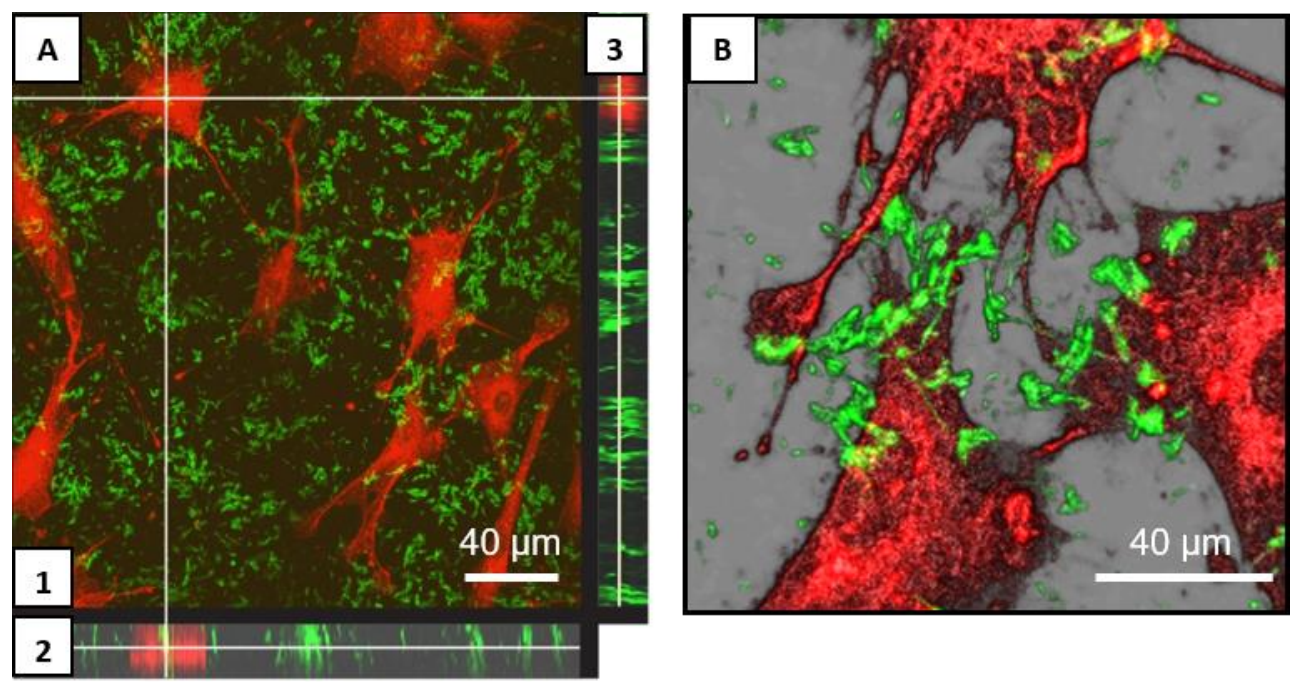

Figure 6: 3D visualization of bacteria (green) on STRO cells (red) adhering on a fibronectin (+Fn) coated sample after 2 hours of co-culture with (A) top view (1) and transversal view (2 and 3) and (B) projected top view with high magnification.

\subsection{Cell adhesion and shape}

Three different cell shape descriptors were compared after 3 hours of co-culture and single cell culture conditions: cell area, circularity and perimeter. These parameters are descriptors for cell adhesion, morphology and spreading onto the surface respectively. As depicted in Figure 7, average cell area, circularity and perimeter did not significantly vary with culture condition when cells were cultured on titanium substrates. In contrast average cell area and circularity decreased in presence of bacteria compared to cells alone on Fn coated titanium. For cells alone, cellular circularity value had decreased on fibronectin while cellular perimeter logically increased, indicating that cells were not as round as on titanium. Interestingly, this effect of fibronectin coating on cell shape descriptors was not visible anymore when cells were co-cultured with bacteria. 

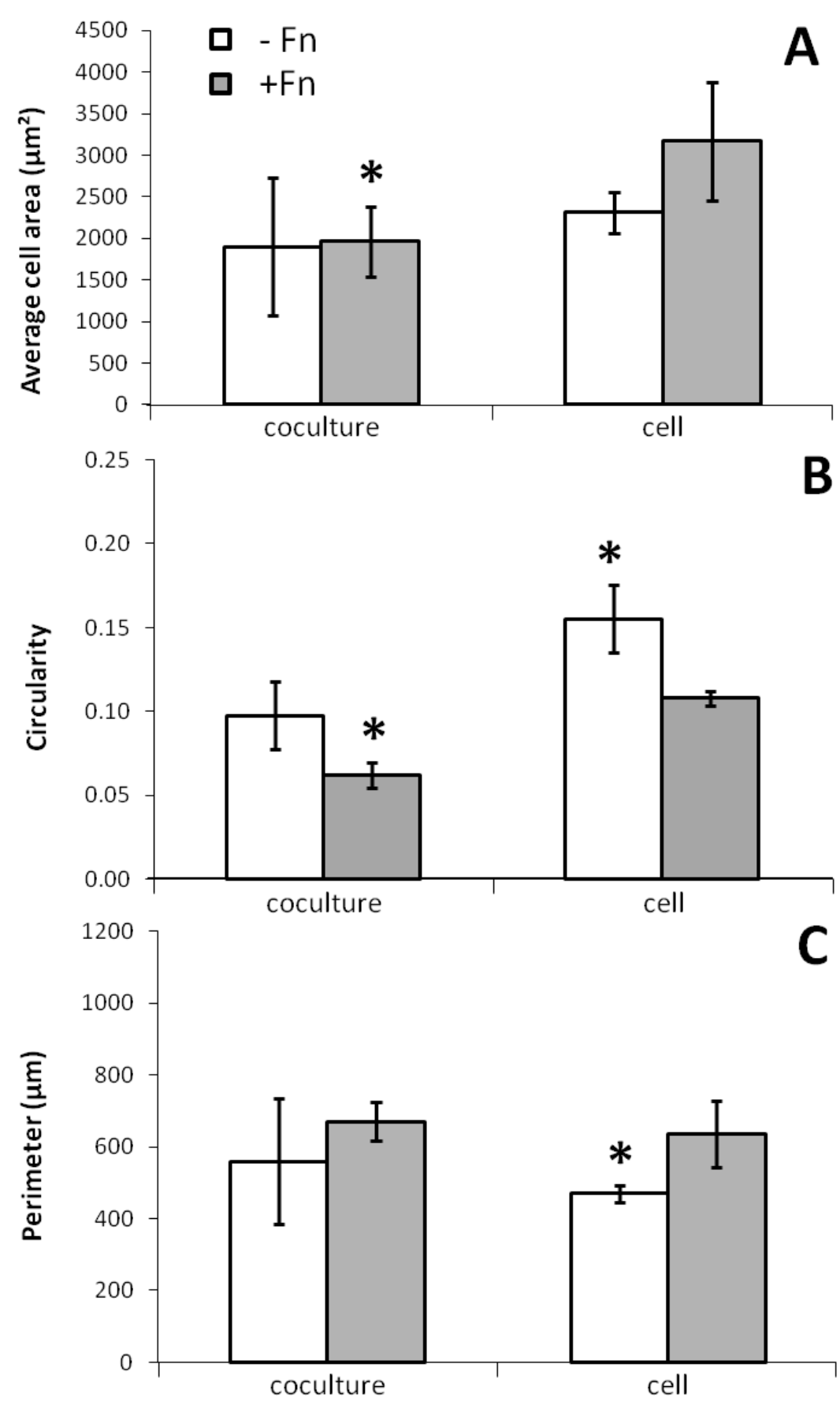

Figure 7: Shape descriptors of cells after 3 hours in co-culture and single cell culture conditions onto titanium surface without (-Fn) or with (+Fn) fibronectin: cellular average area (a), circularity (b) and perimeter (c). *: Significant difference with single cell culture on fibronectin (pFN) coated titanium, assessed with Student $t$-test and ANOVA ( $p$-value $<0.05)$. 


\subsection{Bacteria proliferation and localization}

From inoculation (t0) to 3 hours afterwards, bacterial density was higher on titanium coated with fibronectin compared to uncoated titanium irrespective of culture conditions as shown on Figures 8.A and 8.B. Bacterial proliferation was also significantly enhanced on fibronectin coating compared to uncoated titanium, leading to a time offset in the kinetics of biofilm formation between both surfaces. This was particularly evident for bacteria in co-culture with the mammalian cells (Figure 8.B). Small colonies formed by sessile bacteria and in contact with each other were observed on the entire surface coated with fibronectin (Figures 5.F and $5 . \mathrm{H}$, see zoom in Figure S3), which is characteristic of early stage of biofilm formation. ${ }^{46}$ In contrast, colonies were less present on uncoated titanium (Figures 5.E and 5.G). This revealed a biofilm growth delay on uncoated titanium especially if mammalian cells were present. The quantity and the distribution of bacteria adhered after 3 hours in co-culture on fibronectincoated titanium (Figure 5.H, see zoom in Figure S3) can be interpreted as early stage biofilm, while the sessile bacteria and the sparse colonies observed on uncoated titanium (Figure 5.G) are not yet representative of a biofilm.
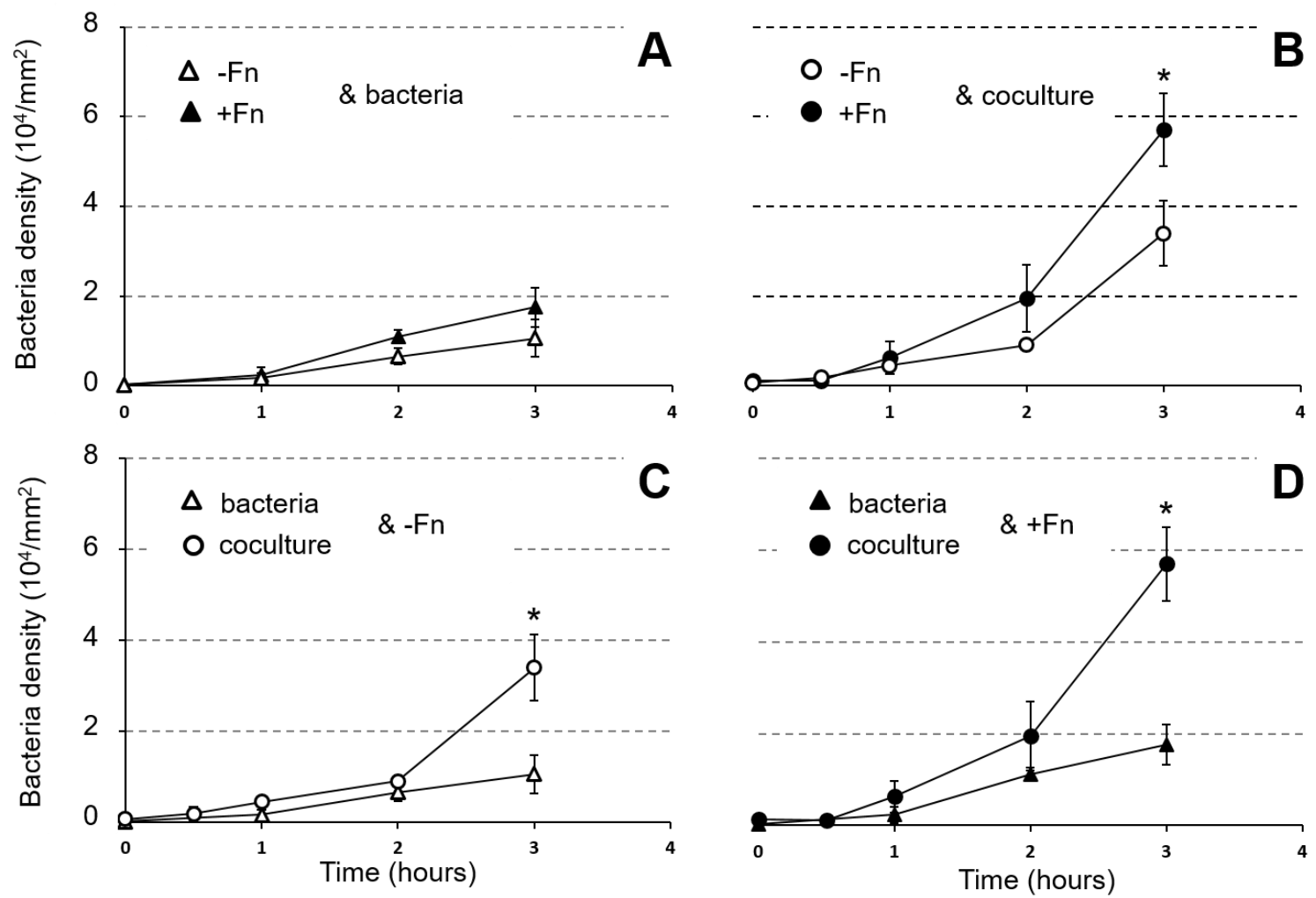

Figure 8: Influence of fibronectin (Fn) coating on bacterial density in single E. coli cultures (A) or in cocultures (B), and influence of co-culture on bacteria density on titanium uncoated (-Fn) (C) or coated 
with fibronectin (+Fn) (D) (*: Significant difference between both displayed conditions at the same culture time, with $p$-value $<0.05)$.

Moreover, as Figures 8.C and 8.D show, bacterial growth was faster in presence of cells irrespective of the substrate. The difference between single and co-culture was significant after 3 hours of culture both on fibronectin and uncoated titanium surfaces.

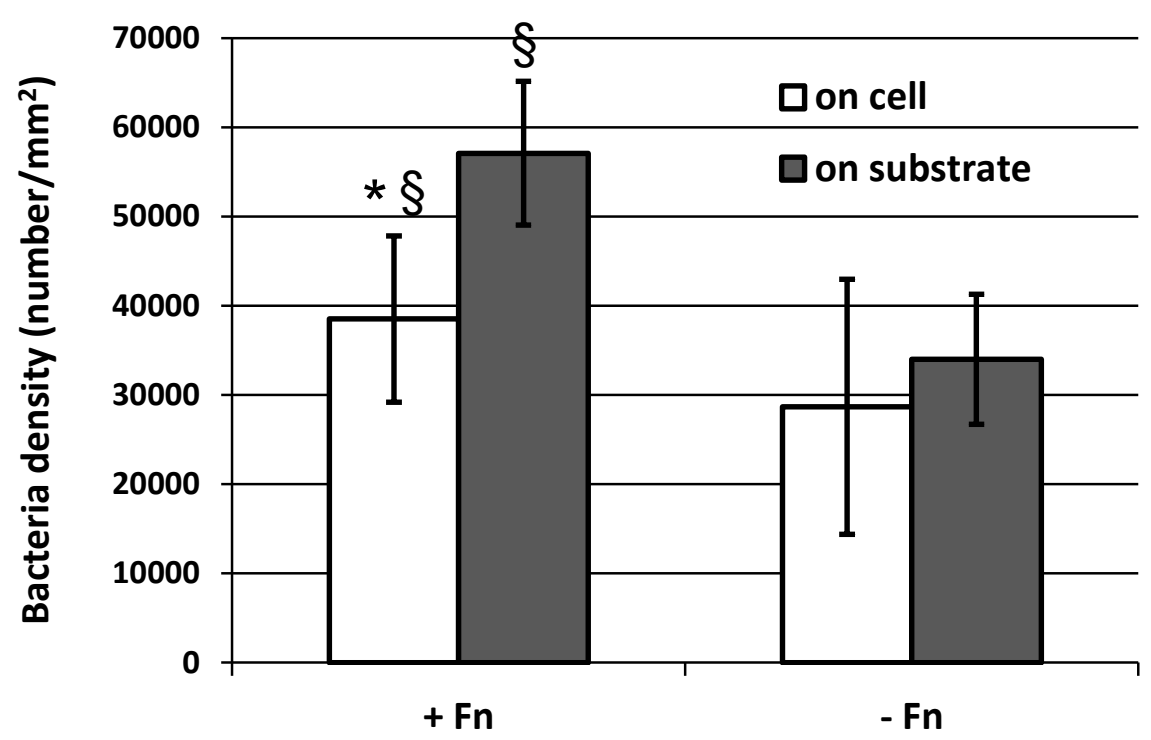

Figure 9: Bacteria density after 3 hours on top of cells or on the substrate with (+Fn) and without (-Fn) fibronectin coating. Significant difference between cell and substrate $\left(^{*}\right)$ and between $+F n$ and $-F n(\S)$ (p-value $<0.05)$.

Figure 9 shows the comparison of bacterial density on top of cells or on the substrate on coated and uncoated titanium substrates. The difference between the density of bacteria upon and beside cells was not significant on titanium substrate. In contrast, bacterial colonization of coated titanium substrate was less on cells than on the substrate. This demonstrates that bacteria were not uniformly distributed over the sample in presence of adsorbed fibronectin. Their localization appeared to be affected by the presence of mammalian cells, resulting in a denser bacterial population on fibronectin-coated titanium than on the cell surface fraction. Interestingly, bacterial proliferation was promoted by the presence of fibronectin both upon and beside cells. A significantly higher density of bacteria 
was observed after 3 hours of culture on fibronectin-coated titanium surfaces as well on the substrate as on cells.

\section{DISCUSSION}

It has been shown in previous studies that $E$. coli bacteria can easily grow on untreated $\mathrm{Ti}$ surfaces. ${ }^{47} \mathrm{E}$. coli has also been found on failing dental titanium implants, confirming their affinity for orthopedic titanium substrates. ${ }^{48}$ These observations were confirmed by our results that showed a high bacterial proliferation on uncoated titanium surfaces. Surface roughness, wettability and substrate composition (such as RGD motifs) have been shown to have significant impact on bacterial adhesion and proliferation. ${ }^{49}$ Moreover, the affinity of $E$. coli for fibronectin has been demonstrated for several strains. ${ }^{50}$ Even, fibronectin is known to be a receptor for the adherence of several E. coli strains onto eukaryotic cells, which further allows bacteria's internalization by the eukaryotic cells. ${ }^{51-52}$ In our experiments, fibronectin coating was done to introduce chemical modification to the titanium surface and favor cell adhesion. As expected, the growth of $E$. coli on fibronectin-coated titanium surface was higher compared to uncoated.

The behavior of osteoblastic cells on titanium is known for being modulated by the surface chemical and topographical properties ${ }^{8,53}$ but also by the shear stress provided by flow. ${ }^{54}$ However, only insignificant shear stress $(0.3 \mathrm{mPa})$ was here induced by the flow of fresh medium compared to those provided by interstitial fluid transport in bone tissue (35-3000 $\mathrm{mPa} .{ }^{54-56}$ On the other hand, it has been shown that surface modification, e.g. increasing of roughness and wettability, can stimulate cell adhesion and differentiation. ${ }^{57}$ For example, mouse osteoblastic cells have been shown to spread and form more cytoplasmic extensions and filopodia on mirror polished titanium than on rough titanium. We confirmed these observations. In addition, similar to bacteria's growth, the spreading of cells was enhanced on substrates with adsorbed fibronectin. Moreover, cells were not as round as on the uncoated titanium substrate. This behavior has also been observed with human fibroblasts adhering on surfaces with adsorbed fibronectin. ${ }^{58}$ Finally, we confirm here that fibronectin promotes both STRO cell spreading and E. coli K12 adhesion and growth on titanium. 
The ability of $E$ coli to adhere cell membrane has been shown to involve specific interactions between fibronectin and specific receptors on E. coli..$^{59-60}$ Therefore, bacteria adhesion is expected to be favored on cells and on a fibronectin coating in contrast to titanium surface. We confirmed the enhancement of bacterial adhesion on fibronectin coating compared to titanium surface. However, we observed that bacteria were more prone to adhere and grow on the fibronectin-coated titanium surface compared to on cells while they adhered similarly on cell membrane and on the uncoated material. Nevertheless the ability of STRO cells to reduce bacterial ability to adhere to cell membrane has already be observed. ${ }^{18}$ Furthermore, this may be the result of cell defense mechanisms such as the controlled release of antimicrobial peptide through bacteria-host cells binding, ${ }^{61}$ which may have adversely and specifically affected the colonization by $E$. coli of the cell membrane.

Nevertheless, the colonization of cells by bacteria in the presence of adsorbed fibronectin on the substrate was slightly yet significantly higher than on cells cultured on uncoated titanium substrate. Vroman effect due to culture medium, especially FBS, may lead to the increase in fibronectin quantity in culture medium by the release of pre-adsorbed fibronectin. ${ }^{62}$ Released fibronectin may then react with cell membrane and finally result in the enhancement of bacterial adhesion on cells compared to with uncoated substrate. However, according to initial protein content of FBS $(\sim 40 \mathrm{mg} / \mathrm{mL})^{63}$ and rate of release expected due to Vroman effect (15-20\% of the adsorbed quantity), ${ }^{62}$ protein content of FBS is not expected to be increased of more than $0.01 \%$ of the initial content if fibronectin is adsorbed at about 1 $\mu \mathrm{g} / \mathrm{cm}^{2} .{ }^{64}$ Therefore, Vroman effect is not expected to be high enough to significantly change the quantity of proteins adsorbed on the cell and consequently change cell invasion by bacteria. The most probable hypothesis is thus based on the capacity of sessile bacteria to spread on bacteria-free part of the surface to colonize it: ${ }^{65}$ Cell invasion was probably the result of spreading from colonies already developed on the fibronectin-coated surface aside from sedimentation and further proliferation of pioneer bacteria directly adhered on the cells. Since bacteria were adhered in higher amount on fibronectin-coated substrate than on uncoated substrate, cell invasion by spreading is thus probably higher on the fibronectincoated substrate. 
We also observed that bacterial proliferation is significantly promoted in the presence of human cells, which seems contradictory to the unfavorable invasion of the cell membrane discussed above. Promotion of bacterial proliferation in coculture could be related to the capacity of bacteria to perceive mammalian cells signal proteins as a trigger for growth and invasion. ${ }^{66}$ For example, cytokines such as interleukins are likely to interact with $E$. coli receptor and to stimulate bacterial growth. TNF $\alpha$ factor was shown to stimulate virulence and invasive behavior in E. coli. Also, adrenaline and noradrenaline enhance growth, motility, virulence and biofilm formation of enterohemorrhagic E. coli. ${ }^{66}$ Since interleukins such as IL1, hormones, and growth factors such as TNF $\alpha$ are secreted in the supernatant of mesenchymal stromal cells in significant amount, ${ }^{67}$ these cellular secretions could be a key factor in increasing bacterial growth we observed under co-culture conditions. However, the positive effect of these factors released in the environment may be locally counteracted by cell defense mechanisms occurring at the cell membrane. ${ }^{61}$ Bacteria proliferation may be thus favored on the coated or uncoated titanium surfaces while specifically prevented on the cell membranes.

Cell number was not affected by the co-culture, which demonstrates the non-lethal effect of E. coli $\mathrm{K} 12$ on cells in our co-culture model. This was expected since E. coli $\mathrm{K} 12$ is considered as a non-pathogenic strain ${ }^{68-69}$ as the level of toxicity of compounds secreted by $\mathrm{K} 12$ (MG1655) strains has been shown to be significantly lower compared to pathogenic E. coli. Molecules such as glyceraldehyde-3-phosphate dehydrogenase (GAPDH) and chaperone Hsp70 that are crucial for bacteria development in host tissues by helping both bacterial adhesion and fighting against host defense mechanisms, are missing in this strain. ${ }^{70-71}$ This absence of GAPDH and Hsp70 in the K12 bacteria secretome can explain the non-lethal effect. Nevertheless, an adverse effect of the co-culture was observed on the cell spreading as shown by the decrease in cell area in co-culture with bacteria compared to cell culture alone. This illustrates that cells are less comfortable in presence of bacteria than alone as previously observed also by other authors (4-8). The reasons are probably that occupation of the surface by bacteria proliferating faster than cells as well as nutrients consumption by bacteria reduce surface area and nutrient availability for cells, ${ }^{34}$ thus inhibiting cell spreading. 
Finally, these results show that our system is suitable for studying complex interactions between bacteria, cells and biomaterial surface. As far as we know our system is one of the rare published systems allowing in situ imaging of live cells and bacteria with the possibility to tune the biomaterial substrate and to follow evolution of the co-culture. Even microtextured or porous surfaces can be considered without compromising quality of the images in contrast to what may be suspected from reflectance and dispersion of incident light on topographically complex surfaces (Figure S5). On fibronectin-coated titanium biomaterials typically, STRO cells were here shown to be not only directly affected by the biomaterial and by the presence of K12 strain E. coli bacteria, probably due to competition for space, but also indirectly by the effect of the biomaterial on bacteria (i.e. more bacteria on cells on the coated versus uncoated surfaces). Bacterial colonization was also shown to be favored by both the presence of cells and the biomaterial. Biological and biochemical processes involved in BAI and infection of cells can be also targeted thanks this co-culture system. Aside from description of the bacterial and human cells and their localization, our method enables harvesting of medium samples throughout the co-culture and their further biochemical analysis e.g. of the secretome. Bacterial species and strains e.g. pathologic strains can be also varied, which will allow the study of specific infection situations such as toxin-related pathogenicity, intracellular infection of cells by bacteria or host defense mechanisms. ${ }^{66,72-74}$ Finally, our co-culture system could be also used as a pre-contamination model by inoculating the bacteria before the cells.

\section{CONCLUSION}

This new dynamic flow chamber system mounted under an upright confocal microscope enables the real-time observation of contamination of pre-adhered STRO cells by E. coli on clinically relevant titanium surface. High quality of the images associated to simultaneous acquisition of fluorescent micrographs of cells and bacteria allows not only the quantification of variations in prokaryote's and eukaryote's behavior during the early stage of a simulated infection on an implanted surface, but also collection of accurate information regarding their localizations and interactions. Moreover, our results suggest that bacteria take advantage of the presence of eukaryotic cells and proliferate faster in co-culture context. These characteristics are shown to be the determining factors in very early steps of infection for the 
"race for the surface", that decide the fate of implant's integration with human preosteoblastic cells. The resulting protocol and analysis prepare the way to a visual approach of the interactions between cells and bacteria, with the opportunity to test various eukaryotic and prokaryotic strains, and use different materials and surface treatments, in a reliable in vitro simulation of BAI. This system is thus an efficient method for studies related to design and function of new biomaterials and represents a real innovation compared to the existing co-culture set-ups.

\section{ACKNOWLEDGEMENTS}

The authors thank CNRS (the French National Center for Scientific Research) and ANR (the French National Research Agency) for their financial support. The authors acknowledge N.T. Wakhloo for English revision of the manuscript.

\section{SUPPORTING INFORMATION}

STRO cells visualized with air and water objectives (Figure S1).

Example of image treatment and analysis (Figure S2).

Detail of Figure 5 to facilitate visualization of the sessile bacteria (Figure S3).

Example of cell masks used for colocalization analysis (Figure S4).

Example of micrographs obtained with a micro-structured surface (Figure S5).

\section{REFERENCES}

1. Grainger, D. W.; Van der Mei, H. C.; Jutte, P. C.; van den Dungen, J. J.; Schultz, M. J.; van der Laan, B. F., Critical factors in the translation of improved antimicrobial strategies for medical implants and devices. Biomaterials 2013, 34 (37), 9237-9243.

2. Engelsman, A. F.; Saldarriaga-Fernandez, I. C.; Nejadnik, M. R.; van Dam, G. M.; Francis, K. P.; Ploeg, R. J., The risk of biomaterial-associated infection after revision surgery due to an experimental primary implant infection. Biofouling 2010, 26 (7), 761-767.

3. Wu, Y.; Zitelli, J. P.; TenHuisen, K. S.; Yu, X.; Libera, M. R., Differential response of Staphylococci and osteoblasts to varying titanium surface roughness. Biomaterials 2011, 32 (4), 951-960. 
4. Wang, Y.; Subbiahdoss, G.; VJ, d.; Libera, M.; Van der Mei, H. C.; Busscher, H. J., Effect of adsorbed fibronectin on the differential adhesion of osteoblast-like cells and Staphylococcus aureus with and without fibronectin-binding proteins. Biofouling 2012, 28 (9), 1011-1021.

5. Vasilev, K.; Sah, V.; Anselme, K.; Ndi, C.; Mateescu, M.; Dollmann, B., Tunable antibacterial coatings that support mammalian cell growth. Nano Lett. 2010, 10 (1), 202-207.

6. Ploux, L.; Anselme, K.; Dirani, A.; Ponche, A.; Soppera, O.; Roucoules, V., Opposite Responses of Cells and Bacteria to Micro/Nanopatterned Surfaces Prepared by Pulsed Plasma Polymerization and UV-Irradiation. Langmuir 2009, 21 (25), 8161-8169.

7. Burton, E. A.; Sirnon, K. A.; Hou, S. Y.; Ren, D. C.; Luk, Y. Y., Molecular Gradients of Bioinertness Reveal a Mechanistic Difference between Mammalian Cell Adhesion and Bacterial Biofilm Formation. Langmuir 2009, 3 (25), 1547-1553.

8. Anselme, K.; Davidson, P.; Popa, A. M.; Giazzon, M.; Liley, M.; Ploux, L., The interaction of cells and bacteria with surfaces structured at the nanometer scale. Acta Biomater. 2010, 2010 (6), 38243846.

9. Franková, J.; Pivodová, V.; Růžička, F.; Tománková, K.; Šafářová, K.; Vrbková, J.; Ulrichová, J., Comparing biocompatibility of gingival fibroblasts and bacterial strains on a different modified titanium discs. Journal of Biomedical Materials Research Part A 2013, 101 (10), 2915-2924.

10. Anagnostou, F.; Debet, A.; Pavon-Djavid, G.; Goudaby, Z.; Hélary, G.; Migonney, V., Osteoblast functions on functionalized PMMA-based polymers exhibiting Staphylococcus aureus adhesion inhibition. Biomaterials 2006, 27 (21), 3912-3919.

11. Gristina, A., Biomaterial-centered infection: microbial adhesion versus tissue integration. Science 1987, 237 (4822), 1588-1595.

12. Zhao, B.; Van der Mei, H. C.; Subbiahdoss, G.; VJ, d.; Rustema-Abbing, M.; Kuijer, R., Soft tissue integration versus early biofilm formation on different dental implant materials. Dent. Mater. 2014, 30 (7), 716-727.

13. Zara, S.; Di, G. M.; D'Ercole, S.; Cellini, L.; Cataldi, A., Anti-adhesive and pro-apoptotic effects of 2-hydroxyethyl methacrylate on human gingival fibroblasts co-cultured with Streptococcus mitis strains. Int. Endod. J. 2011, 44 (12), 1145-1154.

14. Gallorini, M.; di Giacomo, V.; Di Valerio, V.; Rapino, M.; Bosco, D.; Travan, A.; Di Giulio, M.; Di Pietro, R.; Paoletti, S.; Cataldi, A.; Sancilio, S., Cell-protection mechanism through autophagy in HGFs/S. mitis co-culture treated with Chitlac-nAg. J. Mater. Sci. Mater. Med. 2016, 27 (186).

15. Di Giulio, M.; D'Ercole, S.; Zara, S.; Cataldi, A.; Cellini, L., Streptococcus mitis/human gingival fibroblasts co-culture: the best natural association in answer to the 2-hydroxyethyl methacrylate release. APMIS 2012, 120 (2), 139-46. 
16. Cataldi, A.; Gallorini, M.; Di, G. M.; Guarnieri, S.; Mariggio, M. A.; Traini, T., Adhesion of human gingival fibroblasts/Streptococcus mitis co-culture on the nanocomposite system Chitlac-nAg. J. Mater. Sci. Mater. Med. 2016, 27 (5), 88.

17. Zhao, B.; Van der Mei, H. C.; Rustema-Abbing, M.; Busscher, H. J.; Ren, Y., Osteoblast integration of dental implant materials after challenge by sub-gingival pathogens: a co-culture study in vitro. Int. J. Oral Sci. 2015, 18 (7), 250-258.

18. Hindie, M.; Wu, D.; Anselme, K.; Gallet, O.; Di Martino, P., Effects of Fibronectin Coating on Bacterial and Osteoblast Progenitor Cells Adherence in a Co-culture Assay. In Adv. Exp. Med. Biol., Cohen, I. R., Lajtha, A., Lambris, J.D., Paoletti, R., Rezaei, N., Ed. 2016.

19. Zaatreh, S.; Wegner, K.; Strauss, M.; Pasold, J.; Mittelmeier, W.; Podbielski, A., Co-Culture of S. epidermidis and Human Osteoblasts on Implant Surfaces: An Advanced In Vitro Model for ImplantAssociated Infections. PLoS One 2016, 11, 0151534.

20. Zaatreh, S.; Haffner, D.; Strauss, M.; Dauben, T.; Zamponi, C.; Mittelmeier, W., Thin magnesium layer confirmed as an antibacterial and biocompatible implant coating in a coculture model. Molecular Medicine Reports 2017, 15 (4), 1624-1630.

21. Foss, B. L.; Ghimire, N.; Tang, R.; Sun, Y.; Deng, Y., Bacteria and osteoblast adhesion to chitosan immobilized titanium surface: A race for the surface. Colloids and Surfaces B: Biointerfaces 2015, 1 (134), 370-376.

22. Heydorn, A.; Nielsen, A. T.; Hentzer, M.; Sternberg, C.; Givskov, M.; Ersboll, B. K., Quantification of biofilm structures by the novel computer program COMSTAT. Microbiology (Moscow, Russ. Fed.) 2000, 146 (10), 2395-2407.

23. Velve-Casquillas, G.; Le, B. M.; Piel, M.; Tran, P. T., Microfluidic tools for cell biological research. Nano Today 2010, 5 (1), 28-47.

24. Lee, J. H.; Wang, H. J.; Kaplan, J. B.; Lee, W. Y., Microfluidic Approach to Create ThreeDimensional Tissue Models for Biofilm-Related Infection of Orthopaedic Implants. Tissue Engineering Part C: Methods 2011, 17 (1), 39-48.

25. Busscher, H. J.; Van der Mei, H. C., Microbial adhesion in flow displacement systems. Clinical Microbioly Review 2006, 19 (1), 127-141.

26. Subbiahdoss, G.; Kuijer, R.; Grijpma, D. W.; Van der Mei, H. C.; Busscher, H. J., Microbial biofilm growth vs. tissue integration: "The race for the surface" experimentally studied. Acta Biomater. 2009, $5(5), 1399-1404$.

27. Subbiahdoss, G.; Pidhatika, B.; Coullerez, G.; Charnley, M.; Kuijer, R.; Van der Mei, H. C., Bacterial biofilm formation versus mammalian cell growth on titanium-based mono- and bi-functional coating. Eur. Cell. Mater. 2010, 13 (19), 205-213. 
28. Subbiahdoss, G.; Kuijer, R.; Busscher, H. J.; Van der Mei, H. C., Mammalian cell growth versus biofilm formation on biomaterial surfaces in an in vitro post-operative contamination model. Microbiology 2010, 156, 3073-3078.

29. Subbiahdoss, G.; Grijpma, D. W.; Van der Mei, H. C.; Busscher, H. J.; Kuijer, R., Microbial biofilm growth versus tissue integration on biomaterials with different wettabilities and a polymer-brush coating. J. Biomed. Mater. Res. A 2010, 94 (2), 533-538.

30. Rochford, E. T.; Subbiahdoss, G.; Moriarty, T. F.; Poulsson, A. H.; Van der Mei, H. C.; Busscher, H. J., An in vitro investigation of bacteria-osteoblast competition on oxygen plasma-modified PEEK. J. Biomed. Mater. Res. A 2014, 102 (12), 4427-4434.

31. Saldarriaga Fernandez, I. C.; Busscher, H. J.; Metzger, S. W.; Grainger, D. W.; Van der Mei, H. C., Competitive time- and density-dependent adhesion of staphylococci and osteoblasts on crosslinked poly(ethylene glycol)-based polymer coatings in co-culture flow chambers. Biomaterials 2011, 32 (4), 979-984.

32. Subbiahdoss, G.; Fernandez, I. C. S.; Domingues, J. F. D.; Kuijer, R.; Van der Mei, H. C.; Busscher, H. J., In Vitro Interactions between Bacteria, Osteoblast-Like Cells and Macrophages in the Pathogenesis of Biomaterial-Associated Infections. PLoS One 2011, 13 (6).

33. Yue, C. X.; Kuijer, R.; Kaper, H. J.; Van der Mei, H. C.; Busscher, H. J., Simultaneous interaction of bacteria and tissue cells with photocatalytically activated, anodized titanium surfaces. Biomaterials 2014, 35 (9), 2580-2587.

34. Lee, J.-H.; Wang, H.; Kaplan, J. B.; Lee, W. Y., Effects of Staphylococcus epidermidis on Osteoblast Cell Adhesion and Viability on Ti Alloy Surface in Microfluidic Co-Culture Environment. Acta Biomater. 2010, 6 (11), 4422-4429.

35. Cottenye, N.; Anselme, K.; Ploux, L.; Vebert-Nardin, C., Vesicular structures self-assembled from oligonucleotide-polymer hybrids: Mechanical prevention of bacterial colonization upon their surface tethering through hybridization. Adv. Funct. Mater. 2012, 5, 4891-4898.

36. Böhmler, J.; Haidara, H.; Ponche, A.; Ploux, L., Impact of chemical heterogeneities of surfaces on colonization by bacteria. Biomaterials Science \& Engineering 2015, 2015 (1), 693-704.

37. March, J. C.; Rao, G.; Bentley, W. E., Biotechnological applications of green fluorescent protein. . Appl. Microbiol. Biotechnol. 2003, 62 (4), 303-315.

38. Waters, J. C., Accuracy and precision in quantitative fluorescence microscopy. J. Cell Biol. 2009, 185 (7), 1135-1148.

39. Wang, Y.; Shyy, J. Y.; Chien, S., Fluorescence proteins, live-cell imaging, and mechanobiology: seeing is believing. Annu. Rev. Biomed. Eng. 2008, 10, 1-38. 
40. Stephens, D. J.; Allan, V. J., Light microscopy techniques for live cell imaging. Science 2003, 4 (300), 82-86.

41. Sternberg, C.; Bjarnsholt, T.; Shirtliff, M., Methods for Dynamic Investigations of SurfaceAttached In Vitro Bacterial and Fungal Biofilms. Methods in molecular biology (Clifton, N.J.) 2014, 1147, 3-22.

42. Poulouin, L.; Gallet, O.; Rouahi, M.; Imhoff, J. M., Purification and stability of human plasma fibronectin. Protein Expression Purif. 1999, 17, 146-152.

43. Miao, H.; Ratnasingam, S.; Pu, C. S.; Desai, M. M.; Sze, C. C., Dual fluorescence system for flow cytometric analysis of Escherichia coli transcriptional response in multi-species context. J. Microbiol. Methods 2009, 76 (2), 109-119.

44. Rasband, W., U. S. National Institutes of Health, Bethesda, Maryland, USA, ImageJ. 1997.

45. Scherrer, B., Biostatistique. Gaëtan Morin éditeur - Les Editions de la Chenelière inc.: 2007; Vol. 1.

46. Reisner, A.; Haagensen, J. A.; Schembri, M. A.; Zechner, E. L.; Molin, S., Development and maturation of Escherichia coli K-12 biofilms. Mol. Microbiol. 2003, 48 (4), 933-946.

47. Lorenzetti, M.; Dogsa, I.; Stosicki, T.; Stopar, D.; Kalin, M.; Kobe, S., The influence of surface modification on bacterial adhesion to titanium-based substrates. ACS Appl. Mater. Interfaces 2015, 28 (7), 1644-51.

48. Leonhardt, A.; Renvert, S.; Dahlen, G., Microbial findings at failing implants. Clin. Oral Implants Res. 1999, 10 (5), 339-435.

49. Yeo, I. S.; Kim, H. Y.; Lim, K. S.; Han, J. S., Implant surface factors and bacterial adhesion: a review of the literature. Int. J. Artif. Organs 2012, 35 (10), 762-72.

50. Zulfakar, S. S.; White, J. D.; Ross, T.; Tamplin, M. L., Bacterial attachment to immobilized extracellular matrix proteins in vitro. Int. J. Food Microbiol. 2012, 2 (157), 210-217.

51. Gophna, U.; Oelschlaeger, T. A.; Hacker, J.; Ron, E. Z., Role of fibronectin in curli-mediated internalization. FEMS Microbiol. Lett. 2002, 212 (1), 55-58.

52. Yáñez, D.; Izquierdo, M.; Ruiz-Perez, F.; Nataro, J. P.; Girón, J. A.; Vidal, R. M.; Farfan, M. J., The Role of Fibronectin in the Adherence and Inflammatory Response Induced by Enteroaggregative Escherichia coli on Epithelial Cells. Frontiers in Cellular and Infection Microbiology 2016, 6, 166.

53. Anselme, K.; Ponche, A.; Bigerelle, M., Relative influence of surface topography and surface chemistry on cell response to bone implant materials. Part 2: biological aspects. Proc. Inst. Mech. Eng. [H] 2010, 224 (12), 1487-1507.

54. Fritton, S. P.; Weinbaum, S., Fluid and Solute Transport in Bone: Flow-Induced Mechanotransduction. Annual review of fluid mechanics 2009, 41, 347-374. 
55. Ren, L.; Yang, P.; Wang, Z.; Zhang, J.; Ding, C.; Shang, P., Biomechanical and biophysical environment of bone from the macroscopic to the pericellular and molecular level. J. Mech. Behav. Biomed. Mater. 2015, 50, 104-122.

56. Riquelme, M. A.; Burra, S.; Kar, R.; Lampe, P. D.; Jiang, J. X., Mitogen-activated Protein Kinase (MAPK) Activated by Prostaglandin E2 Phosphorylates Connexin 43 and Closes Osteocytic Hemichannels in Response to Continuous Flow Shear Stress. J. Biol. Chem. 2015, 290 (47), 2832128328.

57. Le Guehennec, L.; Soueidan, A.; Layrolle, P.; Amouriq, Y., Surface treatments of titanium dental implants for rapid osseointegration. Dent. Mater. 2007, 23 (7), 844-854.

58. Rico, P.; Hernandez, J. C. R.; Moratal, D.; Altankov, G.; Pradas, M. M.; Salmeron-Sanchez, M., Substrate-Induced Assembly of Fibronectin into Networks: Influence of Surface Chemistry and Effect on Osteoblast Adhesion. Tissue Eng. Part A 2009, 15 (11), 3271-3281.

59. Di Martino, P.; Merieau, A.; Phillips, R.; Orange, N.; Hulen, C., Isolation of an Escherichia coli strain mutant unable to form biofilm on polystyrene and to adhere to human pneumocyte cells: involvement of tryptophanase. Can. J. Microbiol. 2002, 48 (2), 132-137.

60. Hoepelman, A. I.; Tuomanen, E. I., Consequences of microbial attachment: directing host cell functions with adhesins. Infect. Immun. 1992, 60 (5), 1729-1733.

61. Josse, J.; Velard, F.; Gangloff, S. C., Staphylococcus aureus vs. Osteoblast: Relationship and Consequences in Osteomyelitis. Frontiers in cellular and infection microbiology 2015, 5, 85-85.

62. Hirsh, S. L.; McKenzie, D. R.; Nosworthy, N. J.; Denman, J. A.; Sezerman, O. U.; Bilek, M. M. M., The Vroman effect: Competitive protein exchange with dynamic multilayer protein aggregates. Colloids and Surfaces B: Biointerfaces 2013, 103, 395-404.

63. Zheng, X.; Baker, H.; Hancock, W. S.; Fawaz, F.; McCaman, M.; Pungor, E., Proteomic Analysis for the Assessment of Different Lots of Fetal Bovine Serum as a Raw Material for Cell Culture. Part IV. Application of Proteomics to the Manufacture of Biological Drugs. Biotechnol. Prog. 2006, 22 (5), 12941300.

64. Ba, O. M.; Hindie, M.; Marmey, P.; Gallet, O.; Anselme, K.; Ponche, A.; Duncan, A. C., Protein covalent immobilization via its scarce thiol versus abundant amine groups: Effect on orientation, cell binding domain exposure and conformational lability. Colloids and Surfaces B: Biointerfaces 2015, 134, 73-80.

65. Harshey, R. M., Bacterial motility on a surface: many ways to a common goal. Annual Review in Microbiology 2003, 57, 249-273.

66. Kendall, M. M.; Sperandio, V., What a Dinner Party! Mechanisms and Functions of Interkingdom Signaling in Host-Pathogen Associations. . MBio 2016, 1 (7(2)), e01748. 
67. Amable, P. R.; Teixeira, M. V.; Carias, R. B.; Granjeiro, J. M.; Borojevic, R., Protein synthesis and secretion in human mesenchymal cells derived from bone marrow, adipose tissue and Wharton's jelly. Stem Cell Research and Therapy 2014, 16 (5), 53.

68. Blattner, F. R.; Plunkett, I., G.; Bloch, C. A.; Perna, N. T.; Burland, V.; Riley, M., The complete genome sequence of Escherichia coli K-12. Sci. Sports 1997, 5 (277), 1453-1462.

69. Boysen, A.; Borch, J.; Krogh, T. J.; Hjerno, K.; Moller-Jensen, J., SILAC-based comparative analysis of pathogenic Escherichia coli secretomes. J. Microbiol. Methods 2015, 116, 66-79.

70. Egea, L.; Aguilera, L.; Gimenez, R.; Sorolla, M. A.; Aguilar, J.; Badia, J., Role of secreted glyceraldehyde-3-phosphate dehydrogenase in the infection mechanism of enterohemorrhagic and enteropathogenic Escherichia coli: interaction of the extracellular enzyme with human plasminogen and fibrinogen. Int. J. Biochem. Cell Biol. 2007, 39 (6), 1190-1203.

71. Henderson, B.; Martin, A., Bacterial moonlighting proteins and bacterial virulence. Curr. Top. Microbiol. Immunol. 2013, 358, 155-213.

72. Dapunt, U.; Giese, T.; Stegmaier, S.; Moghaddam, A.; Hänsch, G. M., The osteoblast as an inflammatory cell: production of cytokines in response to bacteria and components of bacterial biofilms. BMC Musculoskeletal Disorders 2016, 17 (1), 243.

73. Ribet, D.; Cossart, P., How bacterial pathogens colonize their hosts and invade deeper tissues. Microbes Infect. 2015, 17 (3), 173-183.

74. Stones, D. H.; Krachler, A. M., Against the tide: the role of bacterial adhesion in host colonization. Biochem. Soc. Trans. 2016, 44 (6), 1571. 


\section{TABLE OF CONTENTS GRAPHIC}
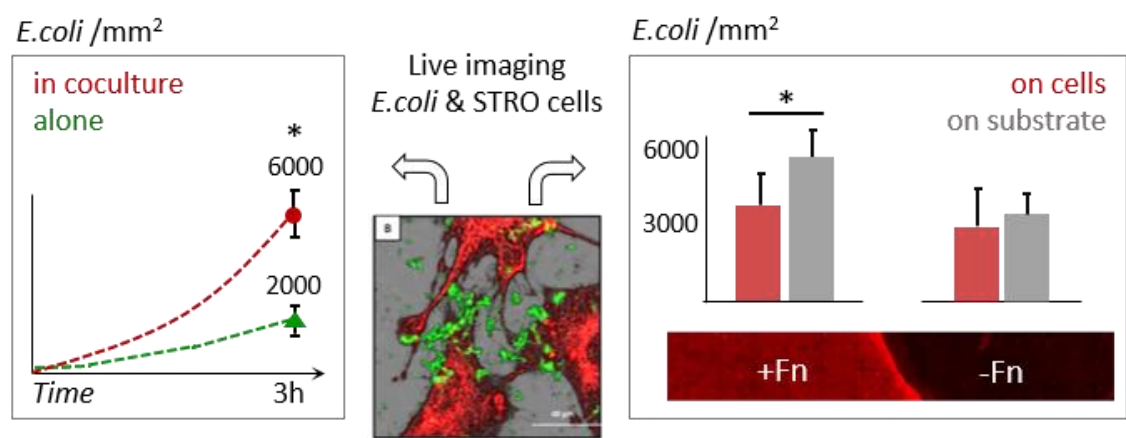